\title{
Firm-Specific Attributes and the Value Relevance of Accounting Information in Nigeria
}

\author{
Gospel J. Chukwu ${ }^{1}$, Isoboye J. Damieibi ${ }^{2} \&$ Emma I. Okoye ${ }^{3}$ \\ ${ }^{1}$ Department of Accountancy, Ken Saro-Wiwa Polytechnic, Bori, Rivers State, Nigeria \\ ${ }^{2}$ Department of Accountancy, Ignatius Ajuru University of Education, Port Harcourt, Nigeria \\ ${ }^{3}$ Department of Accountancy, Nnamdi Azikiwe University, Awka, Nigeria \\ Correspondence: Gospel J. Chukwu, Department of Accountancy, Ken Saro-Wiwa Polytechnic, Bori, Rivers \\ State, Nigeria. E-mail: gospeljchukwu@gmail.com
}

Received: June 30, 2019

doi:10.5539/ijbm.v14n10p12
Accepted: August 5, 2019

Online Published: September 5, 2019

URL: https://doi.org/10.5539/ijbm.v14n10p12

\begin{abstract}
This paper examines how firm-specific attributes affect the value relevance of summary accounting numbers in Nigeria. The paper also investigates whether the adoption of International Financial Reporting Standards (IFRS) affects the relationship between the summary accounting numbers (book value of equity and earnings) and firm-specific characteristics (firm size, liquidity and leverage). Data from 54 firms in 10 sectors of the Nigerian Stock Exchange (covering a period of 6 years, 2009 to 2014, divided into 3 years pre-IFRS period and 3 years IFRS period) were analyzed based on the Ohlson (1995) model. Results from the analyses indicate that firm-specific characteristics affect the relationship between summary accounting numbers and market value, and this effect increased in the period after IFRS adoption. The implication of these findings is that firms seeking to improve their market values must work towards the firm-specific attributes that enhance firm value. By examining the effect of firm-specific attributes on the value relevance of accounting information using data from the Nigerian Stock Exchange, before and after IFRS adoption, this study fills a research gap.
\end{abstract}

Keywords: value relevance, liquidity, firm size, leverage, market valuation, IFRS adoption

\section{Introduction}

One of the aims of the International Accounting Standards Board (IASB) is to develop a single set of standards capable of producing high quality accounting information. The IASB did not define high quality, but it identified faithful representation and relevance as fundamental attributes of useful accounting information. Financial information is regarded as relevant when it can make a difference in the economic decisions of investors, creditors, lenders and other users that need financial information for decision-making. On the other hand, faithfully represented financial information is one that represents the economic phenomena in both words and numbers. The IASB believes that empirical evidence on both relevance and faithful representation (jointly) can be obtained through the correlation of stock prices with accounting numbers (IASB, 2018). Empirical studies that obtain evidence on accounting quality through such statistical procedures are within the field of value relevance research. An accounting amount is said to be value relevant if it is positively associated with stock prices or returns.

This study investigates how firm-specific attributes affect investors' valuation of accounting numbers in the Nigerian equity market. The study focuses on three firm-specific attributes that are frequently mentioned in studies on accounting quality. These characteristics are firm size, leverage and profitability (Hung \& Subrahayam, 2007; Soderstrom \& Sun, 2007). Specifically, the study investigates the value relevance of accounting information in different partitions of each firm-specific attribute.

A number of studies have examined how market values are associated with financial information in Nigeria. These studies, however, did not examine the effect of firm-specific attributes on the relationship. Even the studies on value relevance of financial information often focus on one sector of the Nigerian Stock Exchange (Chukwu, 2017; Chukwu, Ohaka, \& Nwanyanwu, 2017; Ebirien, Chukwu, \& Abiahu, 2019). This study is based on data drawn from 54 firms in 10 sectors of the Nigerian Stock Exchange. Thus, the study provides more representative information on how accounting information affect investors' decision in the Nigerian equity 
market. By identifying categories of reporting entities' attributes that affect the relationship between market value and financial information, the study provides corporate financial management with vital information on firm valuation.

\section{Literature Review and Hypotheses}

The foundation of value relevance studies is the theoretical work of Ohlson (1995) and the extensions by Feltam and Ohlson (1996). These works assume that (i) market value of a firm depends on the present value of expected dividend; (ii) the clean surplus relation holds; and (iii) the time series behaviour of earnings is linear. Combining these assumptions, Ohlson (1995) derived a valuation model which relates market value to accounting information.

The Ohlson (1995) model has triggered considerable empirical research on the association between firm value and accounting information. When this association is positive, the accounting number is said to be value relevant. Value relevance is often operationalized by the $\mathrm{R}^{2}$ from a regression of stock prices (or return) on accounting information. If the $\mathrm{R}^{2}$ from this regression is zero or approximately zero, the accounting number is not value relevant. Value relevance is a measure of accounting quality and this may explain the increasing research interest on the subject.

One area of accounting research that is gaining more attention is whether firm-specific characteristics have any significant effect on accounting quality. For instance, a highly leveraged firm may have to report faithfully represented accounting numbers to win creditors/lenders confidence by convincing them that the accounting amounts in financial reports are useful in evaluating the reporting entity (Burgstahlar, Hail, \& Leuz, 2004).

A few studies have investigated how the value relevance of accounting information is affected by firm-specific attributes in accounting regimes adopting IFRS and domestic national standards. Konstantinos and Athanasious (2011) examined whether the value relevance of accounting information was affected by firm-specific characteristics after the adoption of IFRS in Greece. Using a sample of firms listed on Athens Stock Exchange for the period 2004 to 2005, and the price level specification based on the Ohlson (1995) model, the authors documented that both firm size and fixed asset size had significant effect on the usefulness of summary accounting numbers for equity valuation. Accordingly, the authors concluded that the improvement in accounting quality following the adoption of IFRS in Greece depended on an entity's size and the level of fixed assets.

Alfaraih (2009) also studied the decision-usefulness of earnings and book value for equity investors and how firm-specific characteristics affect accounting quality following the mandatory adoption of IFRS. Using a sample of 1,057 firms listed in Kuwait Stock Exchange from 1995 through 2006, the author identified that certain factors affected how firms complied with IFRS reporting. These factors - leverage, profitability, and liquidity among others - influenced the usefulness of earnings and net asset information for equity investors in Kuwait.

Fillip and Raffournier (2010) used a sample of 48 listed companies in Bucharest Stock Exchange, Romania, to investigate the usefulness of earnings for equity decisions, and the role of of firm size in the relationship. Results of the study showed that the value relevance of smaller firms was higher than that of larger firms. A similar finding was obtained by Chen, Chen and $\mathrm{Su}$ (2001) who studied how equity values in China are associated with financial information. Chen et al. (2001) explained that the finding is consistent with the notion that there is less competing information about smaller firms than larger firms. In contrast, Alfaraih (2009) found that compliance with IFRS financial reporting depends in part on firm size, and the level of compliance affects the quality of financial information. In another Chinese study, Wang, Ali and Al-Akra (2013) examined the value relevance of voluntary disclosures and found that liquidity has a positive significant association with firm value.

Studies that examine the relevance of accounting information for equity decisions (including those comparing the value relevance of IFRS numbers with non-IFRS GAAP data) focus on earnings (or net income) per share and the book value of equity (Barth, Landsman, \& Lang, 2008; Chua, Cheong, \& Gould, 2013; Devalle, Onali, \& Marjarini, 2010). Given the foregoing, the following hypotheses are proposed for this study:

H1: Firm-specific attributes (leverage, liquidity and firm size) affect the value relevance of book value and earnings.

\section{H2: Firm-specific attributes affect the value relevance of accounting information more in the IFRS period}

\section{Research Design}

This study adopts the Ohlson (1995) model which presents market value as a function of book value, earnings and other information. The model has been frequently used by studies that examine the relationship between market value and accounting numbers. The model relies on the adjusted $\mathrm{R}^{2}$ from a regression of share price $(\mathrm{P})$ 
on earnings per share (EPS) and book value of equity per share (BVPS). The data used for this study are drawn from firms in ten different industry categories, and from financial statements covering a period of six years. To ensure that the adjusted $\mathrm{R}^{2}$ from regression analyses in this study is not affected by differences in industry and time, stock price, $\mathrm{P}$, was first regressed on industry and time fixed effects, and the residual from this initial regression, $\mathrm{P}^{*}$, was used in the subsequent regressions. This approach is consistent with the technique adopted by Barth et al. (2008) and Chua et al. (2012). The first model is as follows.

$$
\mathrm{P}_{\mathrm{it}} *=\alpha_{0}+\alpha_{1} \mathrm{EPS}_{\mathrm{it}}+\alpha_{2} \text { BVPS }_{\mathrm{it}}+\varepsilon_{\mathrm{it}}
$$

The second model includes three firm-specific attributes, SIZE (firm size), LEV (leverage), LIQ (liquidity), and three control variables, CFO (cash flow from operations), BG (business growth) and AUD (audit quality). Prior studies have found that business growth, audit quality, and cash flow from operating activities affect the value relevance of accounting information (Cheng, Thomas, \& Liu, 2005; Nayeri, Ghayoumi, \& Bidari, 2012; Robu \& Robu, 2015). The second model is given by equation (2).

$$
\mathrm{P}_{\mathrm{it}}{ }^{*}=\alpha_{0}+\alpha_{1} \mathrm{EPS}_{\mathrm{it}}+\alpha_{2} \mathrm{BVPS}_{\mathrm{it}}+\alpha_{3} \mathrm{SIZE}_{\mathrm{it}}+\alpha_{4} \mathrm{LEV}_{\mathrm{it}}+\alpha_{5} \mathrm{LIQ}_{\mathrm{it}}+\alpha_{6} \mathrm{CFO}_{\mathrm{it}}+\alpha_{7} \mathrm{BG}_{\mathrm{it}}+\alpha_{8} \mathrm{AUD}_{\mathrm{it}}+\varepsilon_{\mathrm{it}}
$$

$$
\begin{array}{ll}
\text { Where: }_{\mathrm{it}} & =\text { share price for firm } i \text { year } t \\
\mathrm{EPS}_{\mathrm{it}} & =\text { earnings per share for firm } i \text { year } t \\
\mathrm{BVPS}_{\mathrm{it}} & =\text { book value of equity per share for firm } i \text { year } t \\
\mathrm{SIZE}_{\mathrm{it}} & =\text { natural logarithm of total revenue in 000s of Nigerian naira for firm } i \text { year } t . \\
\mathrm{LEV}_{\text {it }} & =\text { is the end of year total liabilities divided by total assets for firm } i \text { year } t . \\
\mathrm{LIQ}_{\text {it }} & =\text { is the end of year current assets divided by current liabilities for firm } i \text { year } t . \\
\mathrm{CFO}_{\text {it }} & =\text { is the end of year amount of cash flow from operations divided by total assets for } \\
\mathrm{BG}_{\mathrm{it}} & =\text { firm } i \text { year } t \text {. } \\
\mathrm{LEV}_{\mathrm{it}} & =\text { is the annual percentage change in sales for firm } i \text { year } t . \\
\mathrm{AUD}_{\mathrm{it}} & =\text { an indicator variable set to one for the big four audit firms,; zero otherwise } \\
\varepsilon_{\mathrm{it}} & =\text { error term } \\
\alpha & =\text { regression coefficient }
\end{array}
$$

We use the adjusted $\mathrm{R}^{2}$ from the two models in determining whether firm-specific attributes affect the value relevance of accounting information. If the explanatory power of model 2 is greater than that of model 1 it would mean that firm-specific attributes affect how the market values accounting information. We also run regressions separately for our pre-IFRS sub-sample and post-IFRS sub-sample, and the adjusted $\mathrm{R}^{2} \mathrm{~s}$ from these sub-samples enable us to determine whether the mandatory adoption of IFRS has any effect on how firm-specific attributes affect the value relevance of accounting information.

Further, we use the chow test for validity of combining two samples to fit a regression model in determining whether the mandatory adoption of IFRS has introduced such structural break in the association of accounting numbers with share prices that it would be unreasonable to pool data from the pre-IFRS period with data from IFRS period in a single regression model. This test is given by the following equation:

$$
\mathrm{F}=\frac{\mathrm{RSSc}-\left(\mathrm{RSS}_{1}+\mathrm{RSS}_{2}\right) / \mathrm{k}}{\left(\mathrm{RSS}_{1} 1+\mathrm{RSS}_{2}\right) \mathrm{n}-2 \mathrm{k}}
$$

In this model, $\mathrm{RSS}_{\mathrm{C}}$ is the residual sum of squares for the combined sample, the pre-IFRS and post-IFRS sample; $\mathrm{RSS}_{1}$ is the residual sum of squares for the first sample, the sample based on data from the pre-IFRS period; $\mathrm{RSS}_{2}$ is the residual sum of squares for the post-IFRS sample; $k$ is the number of parameters, and $n$ is the number of observations. The chow test is used to determine whether the parameters are stable (have not shifted) between the two samples. Therefore, the null hypothesis would be that the coefficients on the accounting variables are stable and have not shifted from one sample to another. If the null hypothesis is rejected it would mean that the parameters are not stable between the two periods and combining these subsamples in a single regression will produce much larger residuals (Dougherty, 1992). In the context of our study, the rejection of the null hypothesis would suggest that the adoption of IFRS has introduced a structural break in the relationship between share price and accounting variables such that the coefficients differ significantly between the pre- and post-IFRS reporting periods and it would be inappropriate to run a combined regression as the residuals on the whole will be much larger. 


\section{Sample Selection and Data}

This study is based on listed companies in Nigeria that prepared their financial statements using IFRS with effect from 1 January 2012, the date of mandatory IFRS adoption by public interest entities in Nigeria. Companies in the financial sector were excluded because of the additional regulations that govern their financial reporting. Also excluded are companies that did not prepare their financial statements under IFRS at 31 December 2012. The sample selection procedure is detailed as follows:

Table 1. Sample Selection Procedure

\begin{tabular}{ll}
\hline Total number of listed companies in Nigerian Stock Exchange & 204 \\
\hline Less Total number of companies in the financial sector & 57 \\
Total number of non-financial companies & 147 \\
Less Number of companies with a year end at a date other than 31 December & 43 \\
Number of non-financial companies whose year end is 31 December & 104 \\
Less Number of non-financial companies whose annual reports and accounts for 2008 to 2013 were not available at & 50 \\
the Port Harcourt Stock Exchange & 54 \\
Number of companies in the sample & \\
Number of reporting years & \\
$\quad \begin{array}{l}\text { Pre IFRS period (2009 to 2011) } \\
\text { Post IFRS period (2012 to 2014) }\end{array}$ \\
Total reporting period & 3 years \\
\hline
\end{tabular}

Notes. Our source for listed companies is the 2010/2011 Fact Book of the Nigerian Stock Exchange.

Table 2 presents the breakdown of our sample based on the industry categories of the Nigerian Stock Exchange. There are eleven industry categories in the main board (equities) of the Nigerian Stock Exchange and our selected firms are spread across these industries except the financial services sector which was excluded because of the additional regulations governing their financial reporting.

Table 2. Industry breakdown of the sample

\begin{tabular}{lll}
\hline NSE Industry category & Code & Number of firms \\
\hline Agriculture & 1 & 3 \\
Conglomerates & 2 & 4 \\
Construction and real estate & 3 & 1 \\
Consumer goods & 4 & 7 \\
Industrial goods & 5 & 12 \\
Natural resources & 6 & 2 \\
Oil and gas & 7 & 7 \\
Services & 8 & 10 \\
Health care & 9 & 4 \\
ICT & 10 & 4 \\
Financial services & 11 & Excluded in the study \\
TOTAL & & 54 \\
\hline
\end{tabular}

Note. The industry code was supplied by the authors for ease of analysis. As stated earlier, firms in the financial services sector were excluded from our sample because of the additional regulations governing their financial reporting.

Data on accounting numbers were obtained from the annual reports and accounts of selected companies for six years divided into three years pre-IFRS period (2009 to 2011) and three years of IFRS reporting (2012 to 2014). The first IFRS financial statements were issued by listed companies and other entities of significant public interest with effect from 31 December 2012; therefore, the post IFRS sub-sample justifiably begins with accounting data obtained from published financial statements for the year ended 31 December 2012. The stock prices used in the regression analyses were extracted from the Central Securities System website of the Nigerian Stock Exchange. 


\section{Univariate Analysis}

Table 3 presents the correlation matrix between share price, basic value relevance explanatory variables (EPS, BVPS), firm-specific characteristics (SIZE, LEV, LIQ) and control variables (CFO, BG, AUD). A significant positive association exists between share price and earnings per share (EPS), indicating that Nigerian investor place great value on firms with higher EPS. There is a significant positive relationship between share price and firm size (SIZE), suggesting that investors' perception of firm value increases with firm size. There is a statistically significant positive association between leverage (LEV) and share price, firm size (SIZE), liquidity and the quality of auditors suggesting that firms with high leverage are able to produce more value relevant accounting information than firms with lesser debt / equity ratio.

Table 3. Correlation of variables in Model 2

\begin{tabular}{|c|c|c|c|c|c|c|c|c|c|}
\hline & $\mathrm{P}^{*}$ & EPS & BVPS & SIZE & LEV & LIQ & $\mathrm{CFO}$ & $\mathrm{BG}$ & AUD \\
\hline $\mathrm{P} *$ & 1.000 & & & & & & & & \\
\hline EPS & $.620 * * *$ & 1.000 & & & & & & & \\
\hline BVPS & $.448 * * *$ & $.506^{* * *}$ & 1.000 & & & & & & \\
\hline SIZE & $.486^{* * *}$ & $.455 * * *$ & $.560 * * *$ & 1.000 & & & & & \\
\hline LEV & $.239 * * *$ & $.091 *$ & .056 & $.161 * * *$ & 1.000 & & & & \\
\hline LIQ & .036 & .066 & $.017 * *$ & $.103 * *$ & $.487 *$ & 1.000 & & & \\
\hline $\mathrm{CFO}$ & $.221 * * *$ & $.286 * * *$ & .112 & $.255^{* *}$ & $-.104 * * *$ & -.049 & 1.000 & & \\
\hline BG & .067 & $.106^{* *}$ & $.163 * * *$ & $.101^{* *}$ & .060 & -.034 & .012 & 1.000 & \\
\hline AUD & $.339 * * *$ & $.227 * * *$ & $.288 * * *$ & $.516^{* * *}$ & $.137 * * *$ & .014 & $.145^{* * *}$ &, 022 & 1.000 \\
\hline
\end{tabular}

Notes. This table presents a Pearson correlation of the accounting variables used in this study. Variables are as defined in the research design section. *,***** Correlation is significant at $1 \%, 5 \%$ and $10 \%$ level, respectively.

On book value of equity (BVPS), there is a positive association between BVPS and liquidity (LIQ) at $5 \%$ percent level, suggesting that firms with higher book value of equity record higher liquidity. Also, a significant positive relationship is found between book value of equity (BVPS), firm size (SIZE), cash flow from operation (CFO), business growth (BG) and big 4 auditors (AUD). Auditors (AUD) are also positively and significantly correlated with profitability (EPS), firm size (SIZE), leverage (LEV) and cash flow from operations (CFO) at the 1 percent level. It is noteworthy that none of the correlations is up to 70 per cent, suggesting that the issue of multicollinerity is not a problem in this study.

\section{Empirical Results and Discussion}

\subsection{Value Relevance of Accounting Information: Pre IFRS Reporting Periods}

Results of data analyses based on the first model are presented Table 4. Panel A presents the results for the preIFRS period, while Panel B presents the results for the IFRS period. The combined data (pre IFRS and IFRS reporting periods) is presented in panel C. Across the three panels, the coefficients for earnings (EPS) and book value of equity (BVPS) are positive and significant at the $1 \%$ percent level, indicating that the two variables are value relevant in both the pre-IFRS and IFRS reporting periods.

The adjusted $\mathrm{R}^{2}$, which indicates the explanatory power of the regression model, is higher in the IFRS reporting period (43\%) than the pre IFRS period (41\%). As in other value relevance studies (e.g. Barth et al. 2008), the adjusted $\mathrm{R}^{2}$ from a regression of stock price on EPS and BVPS is a measure of the value relevance of accounting information, accordingly, the value relevance of accounting information is higher in the IFRS reporting period than in the pre- IFRS period.

The regression results of the second model are presented in Table 5. Similar, to the first model, the adjusted $\mathrm{R}^{2}$ for the pre-IFRS period (46\%) reported in Panel A of the Table, is lower than that of the post-IFRS period (49\%) reported in Panel B of the Table. The consistent results from the two models indicate that IFRS accounting numbers, in totality, provides, more value relevant accounting numbers, supporting the view that the value relevance of accounting information is greater in the IFRS period than the pre-IFRS period (Chua et al. 2008). 
Table 4. Results of regression analysis from Model 1 (Basic value relevance model)

\begin{tabular}{|c|c|c|c|c|c|c|}
\hline & \multicolumn{2}{|c|}{$\begin{array}{l}\text { Panel A } \\
\text { Pre IFRS period }\end{array}$} & \multicolumn{2}{|c|}{$\begin{array}{l}\text { Panel B } \\
\text { Post IFRS period }\end{array}$} & \multicolumn{2}{|c|}{$\begin{array}{l}\text { Panel C } \\
\text { Combined data }\end{array}$} \\
\hline & Coeff & t-stats & Coeff & t-stats & Coeff & t-stats \\
\hline Constant & -.652 & -5.594 & -.677 & -5.005 & -.656 & -7.452 \\
\hline EPS & .002 & $7.872 * * *$ & .002 & $6.245^{* * *}$ & .002 & $10.061 * * *$ \\
\hline BVPS & .024 & $3.402 * * *$ & .028 & $3.371 * * *$ & .025 & $4.72^{* * *}$ \\
\hline \multicolumn{7}{|c|}{ Model summary } \\
\hline \multicolumn{2}{|c|}{ Adj $R^{2}$} & .410 & .429 & & .422 & \\
\hline \multicolumn{2}{|c|}{ F change } & 56.48 & 57.995 & & 115.313 & \\
\hline \multicolumn{2}{|c|}{ Durbin Watson } & 2.151 & 2.230 & & 2.219 & \\
\hline \multicolumn{2}{|l|}{$\mathrm{N}$} & 161 & & 153 & & 314 \\
\hline Chow test & F cal 0.336 & F crit 2.60 & & & & \\
\hline
\end{tabular}

Notes. This table presents the results of regression analysis of our data based on equation 1. Variables are as defined in the research design section. * $, * *, * *$ Correlation is significant at $1 \%, 5 \%$ and $10 \%$ level, respectively.

Table 5. Results of regression analysis from Model 2 and Chow test result

\begin{tabular}{|c|c|c|c|c|c|c|c|c|c|}
\hline & \multirow{2}{*}{$\begin{array}{l}\text { Panel A } \\
\text { Coeff }\end{array}$} & \multicolumn{2}{|c|}{ Pre IFRS period } & \multirow{2}{*}{$\begin{array}{l}\text { Panel B } \\
\text { Coeff }\end{array}$} & \multicolumn{2}{|c|}{ Post IFRS period } & \multicolumn{3}{|c|}{ Panel C Pre \& Post combined } \\
\hline & & t-stat & VIF & & t-stat & VIF & Coeff & t-stat & VIF \\
\hline Constant & -3.415 & -3.322 & & -3.397 & -2.961 & & -3.433 & 4.590 & \\
\hline EPS & .002 & $6.732 * * *$ & 1.363 & .002 & $5.410^{* * *}$ & 1.734 & .002 & $8.801^{* * *}$ & 1.512 \\
\hline BVPS & .014 & $1.861 *$ & 1.563 & .022 & $2.557^{* *}$ & 1.957 & .017 & $3.050^{* * *}$ & 1.711 \\
\hline SIZE & .103 & 1.506 & 2.008 & .072 & .973 & 2.059 & .093 & $1.882 *$ & 2.008 \\
\hline LEV & 1.375 & $3.009 * * *$ & 1.463 & 2.017 & $3.307 * * *$ & 1.465 & 1.630 & $4.570^{* * *}$ & 1.407 \\
\hline LIQ & .128 & $1.857^{*}$ & 1.433 & .167 & 1.136 & 1.418 & .139 & $2.290^{* *}$ & 1.359 \\
\hline $\mathrm{CFO}$ & .508 & .648 & 1.235 & 1.180 & 1.361 & 1.151 & .832 & 1.452 & 1.174 \\
\hline BG & -.019 & -.747 & 1.085 & .220 & .591 & 1.033 & .018 & -.722 & 1.032 \\
\hline AUD & .372 & 1.553 & 1.419 & .280 & 1.095 & 1.447 & .348 & $2.010^{* *}$ & 1.394 \\
\hline \multicolumn{10}{|c|}{ Model summa } \\
\hline \multicolumn{2}{|c|}{$\operatorname{Adj}^{2}$} & & .458 & & & .487 & & & .484 \\
\hline \multicolumn{2}{|l|}{ F change } & & 17.92 & & & 19.00 & & & 37.7 \\
\hline \multicolumn{2}{|c|}{ Durbin Watson } & & 2.218 & & & 2.203 & & & 2.241 \\
\hline \multicolumn{2}{|l|}{$\mathrm{N}$} & & 161 & & & 153 & & & 314 \\
\hline
\end{tabular}

Chow test

$$
\text { F cal } \quad 0.233
$$

F crit 2.41

Notes. This table presents the results of regression analysis of our data based on equation 2. The table also presents the result of chow test based on the residual sum of squares from our subsamples and combined samples. Variables are as defined in the research design section. Correlation $* * *, * *$ is significant at $1 \%, 5 \%$ and $10 \%$ level, respectively.

\subsection{Firm-Specific Attributes and Value Relevance of Accounting Information}

Results in Table 4 and Table 5 show that the inclusion of firm-specific variables in equation 2 improved the explanatory power of our models (and consequently, the value relevance of book value and earnings) in both pre-IFRS and IFS reporting periods. For ease of reference, the adjusted $\mathrm{R}^{2} \mathrm{~s}$ from the two models are presented in Table 6.

Panel A of Table 6 shows the adjusted $\mathrm{R}^{2} \mathrm{~s}$ for the pre-IFRS period, Panel B shows the adjusted $\mathrm{R}^{2} \mathrm{~s}$ for the IFRS period, while Panel $\mathrm{C}$ shows the adjusted $\mathrm{R}^{2} \mathrm{~s}$ from pooled data. Across the three panels, the adjusted R-squares from equation 2 is higher than that of equation 1, indicating that the firm-specific attributes in our study (leverage, liquidity and firm size) have the combined effect of positively affecting the value relevance of book value and earnings; thus, the proposition that firm-specific attributes affect the value relevance of accounting information (hypothesis 1) is supported. Table 6 also shows that the adjusted $R^{2} s$ (in the model with firm-specific attributes) are higher in the IFRS period than in the pre-IFRS period, supporting hypothesis 2 
Table 6. Adjusted $\mathrm{R}^{2}$ from model 1 and model 2

\begin{tabular}{llll}
\hline & Panel A & Panel B & Panel C \\
& Adjusted R & $\begin{array}{l}\text { Adjusted R } \\
\text { Adjusted R }\end{array}$ \\
& Pre-IFRS period & IFRS period & Combined Data \\
\hline Basic value relevance (equation 1) & 0.410 & 0.429 & 0.422 \\
Model including firm-specific attributes (equation 2) & 0.458 & 0.487 & 0.484 \\
\hline
\end{tabular}

Source: Tables 3 and 4 .

\subsection{Leverage and Value Relevance of Accounting Information}

The results presented in Table 5 show that in all the three panels, leverage is positively significant at the 1 percent level, suggesting that firms with relatively higher debt ratio present more value relevant accounting information. Prior studies provide mixed evidence on how leverage affects accounting quality. For instance, Burgstahlar et al. (2004) suggest that highly leveraged firms report faithfully represented accounting numbers to win investors' confidence, but results of Defond and Jiambalvo (1994) cited in Isidro and Roanic (2012) indicate that high leverage will create incentives for the manipulation of accounting numbers in order to meet debt commitments. The case of Nigeria appears to be consistent with the findings of Burgstahlar et al. (2004). The correlation matrix (Table 3) shows that leverage is significantly and positively associated with auditors (AUD), suggesting that a large number of the listed firms reporting higher debt ratio are audited by the big four audit firms (KPMG, PWC, Ernst \& Young and Deloitte). It is possible that investors in Nigeria perceive the accounting numbers from these firms as more faithfully representing the underlying, economic conditions of the firms, given the experience of some banks which collapsed in 2008 despite the impressive financials they were reporting before the collapse. This thinking may have informed investors' favorable perception towards reporting relatively higher leverage numbers.

\subsection{Size and Value Relevance}

The combined data presented in Table 5 (panel C) shows that firm size is positively significant at 10 percent level. This means that larger firms report more value relevant accounting numbers than smaller firms. The accounting numbers of larger firms are perceived as being more useful for equity valuation than those of smaller firms because larger firms receive more media coverage and other forms of public attention (such as analysts following) and consequently their stock prices tend to incorporate more public information than smaller firms (Chen et al., 2001).

In the correlation table (Table 3), firm size is significantly and positively associated with business growth. Investors are, therefore, likely to perceive large firms as capable of surviving turbulent economic environments through more effective business growth strategies.

\subsection{Liquidity and Value Relevance}

Results presented in Table 5 shows that liquidity is positively significant in the pre-IFRS period but not in the IFRS period. Accordingly, the results show that liquidity is significantly more value relevant in the pre-IFRS period than the IFRS reporting period. Wang et al. (2013) found that liquidity significantly affects how the Chinese equity market value accounting information. Our overall result as shown in Table 5 suggests that liquidity contributes to the value relevance of earnings and book value, although the results in Panel A and Panel $\mathrm{B}$, show that liquidity is significantly more value relevant in the pre-IFRS reporting period than the IFRS period. The possible reason for this result is that part of our pre-IFRS period substantially coincides with the period of financial crises (2008-2010) in Nigeria. In such periods investors expectedly react strongly to liquidity as liquidity inadequacies can lead to firm collapse as in the case of Skye Bank Plc in Nigeria. As the economy moves away from financial crises, the use of liquidity for firm value is likely to decline as investors will expect firms to maximally deploy available cash resources to remain competitive.

\subsection{Other results}

Table 4 presents the chow test for validity of combining the pre-IFRS and IFRS reporting samples based on our basic value relevance model, while Table 5 presents the chow test results for our expanded value relevance model. The results in both cases show that the $\mathrm{F}$ calculated is lesser that the $\mathrm{F}$ critical, suggesting that there is no statistical evidence of structural break in financial reporting data following the introduction of IFRS in Nigeria. The implication of this is that our data from the two sub-samples can be combined into single regression model without violating any statistical concern. In this case, our result is not consistent with Devalle et al. (2010) 
whose chow test result was significant in the combined samples (pre-IFRS and IFRS data) for some European countries. Prior to the adoption of IFRS in Nigeria, the Nigerian Accounting Standards Board (precursor to the Financial Reporting Council of Nigeria) issued Statements of Accounting Standards which complied substantially with corresponding IFRSs. This may explain the insignificance of the chow test for data drawn from the pre-IFRS and IFRS reporting periods in Nigeria.

Table 5 presents the Variance Inflation Factor (VIF) for the various predictors in our expanded value relevance model. None of the VIFs across the three panels in Table 5 is more than 3. Also, in the correlation matrix in Table 3, there is no correlation that exceeds 70 percent. These facts show that the problem of multicollinearity is not an issue of concern in our results. The Durbin - Watson statistic reported in Table 4 and 5 suggest that the error terms in our model are not auto correlated.

\section{Conclusion}

In this study, two hypotheses on the value relevance of accounting information and its relationship with firm-specific attributes were tested. The data analyzed were drawn from the financial statements of fifty-four firms in ten different sectors of the Nigerian Stock Exchange. The data covered a period of six years (2009 to 2014), divided into three years pre- IFRS period and three years IFRS reporting period. Results show that the association of market value with accounting information increased in the IFRS reporting period, and firm-specific attributes (leverage, firm size and liquidity) affect how equity investors value accounting numbers.

The results further show that liquidity was not value relevant in IFRS reporting period although investors found this firm attribute useful for decision making in the pre-IFRS reporting period. These results lead to the conclusion that IFRS accounting numbers are useful for decision making, but accounting regulators must work towards ensuring that investors have confidence in the accounting numbers of reporting entities irrespective of their firm-specific characteristics.

\section{Limitations and Suggestions for Further Studies}

This paper excluded firms in the financial sector because of the special regulations they are subjected to in Nigeria. Again, the study used only secondary data. A study that uses both primary and secondary data may be more informative. Therefore, further research on the subject of this study should consider using both data sets. Further studies should also consider using data from both financial and non-financial sectors, and comparing the both set of data to determine whether differences between financial and non-financial sector can impact the value relevance of firm-specific attributes in Nigeria.

\section{References}

Alfaraih, M. (2009). Compliance with International Financial Reporting Standards (IFRS) and the value relevance of accounting information in emerging stock markets: Evidence from Kuwait (Doctoral Dissertation, Queensland University of Technology). Retrieved from http://eprints.qut.ent.au/363774

Barth, M. E., Landsman, W., \& Lang, M. H. (2008). International Accounting Standards and accounting quality. Journal of Accounting Research, 46, 467-498. https://doi.org/10.1111/j.1475.679x.2008.00287.x

Burgsteihler, D., Hail, L., \& Leuz, C. (2009). The importance of reporting incentives: Earnings management in European private and public firms. Working paper, The Wharton Financial Institution Center. Retrieved from http://fic.wharton.upenn.ed/fic/papers/04/04 07.pdf

Cheng, C.A., Thomas, W.B. \& Liu, C. (2005). Incremental value relevance of cash flow components: Estimating the potential valuation effects of operating cash flows misspecification. SSRN Electronic Journal. https://doi.org/10.2139/ssrn.817247

Chen, C. J. P., Chen, S. \& Su, X. (2001). Is accounting information value -relevance in emerging Chinese stock market? Journal of International Accounting, Auditing \& Taxation, 10, 1-22. https://doi:org/10.1016-9518(01)00033-7

Chua, Y. L., Cheong, C. S., \& Gould, G. (2013). The impact of mandatory IRFS adoption on accounting quality: Evidence from Australia. Journal of International Accounting Research, 11(1), 119-146. https://doi.org/10.2308/jiar-10212

Chukwu, A. N., Ohaka, J., \& Nwanyanwu, L. A. (2017). Intangible assets and market value of quoted deposit money banks in Nigeria. UNIPORT Journal of Business, Accounting \& Finance Management, 8(1), 184-199

Chukwu, G. J. (2017). Market valuation of IFRS reconciliation adjustments in the insurance industry: Evidence 
from Nigeria. Journal of Global Accounting, 5(1), 224-231

Devalle, A., Onali, E., \& Marjarini, R. (2010). Assessing the value relevance of accounting data after the introduction of IFRS in Europe. Journal of International Financial Management \& Accounting, 21(2), 85-119. https://doi.org/10.1111/j.1467-646X.2010.01037.x

Dougherty, C. (1992). Introduction to Econometrics. New York: Oxford University Press

Ebirien, G. I., Chukwu, G. J., \& Abiahu, M. C. (2019). Market valuation of related-party loans in the Nigerian insurance industry. Proceedings of the $5^{\text {th }}$ Annual International Academic Conference on Accounting \& Finance, of the Institute of Chartered Accountants of Nigeria, 532-542.

Feltham, G. A., \& Ohlson, J.A. (1995). Valuation and clean surplus accounting for operating and financial activities. Contemporary Accounting Research, 11(2), 689-731. https://doi.org/10.1111/j.1911-3846.1995.tboo462.x

Fillip, A. \& Raffournier, B. (2010). The value relevance of earnings in a transition economy: The case of Romania. The International Journal of Accounting, 45, 77-103. https://doi.org/10.1016/j.intacc.2010.01.004

Hung, M., \& Subrahanyam, K. R. (2007). Financial Statement effect of adopting International Financial Reporting Standards: The case of Germany. Review of Accounting Studies, 12, 623-657. https://doi.org/10.1007/s11142-007-9049-9

International Accounting Standards Board. (2018). International Financial Reporting Standards: Official pronouncements issued at 1 January 2018. London: IFRS Foundation

Isidro, H., \& Roanic, I. (2012). Firm incentives, institutional complexity and the quality of "harmonised" accounting numbers. The International Journal of Accounting, 47(4), 407-436. https://doi.org/10.1016/j-intacc.2012.10.007

Konstantinos, P. P., \& Athanasious, B. P. (2011). The value relevance of accounting information under Greek and International Financial Reporting Standards: The influence of firm-specific characteristics. International Research Journal of Finance and Economics, 76, 6-23. Retrieved from http://www.internationalresearchjournalof financeandeconomics.com

Nayeri, M. D., Ghayoumi, A. F., \& Bidari, M. A. (2012). Factors affecting the value relevance of accounting information. International Journal of Academic Research in Accounting, Finance and Management Sciences, 2(2), 76-84.

Ohlson, J. A. (1995). Earnings, book values, and dividends in equity valuation. Contemporary Accounting Research, 11(2), 661-687.https://doi.org/10.1111/j.1911.3846.1995tb00461.x

Robu, M. A., \& Robu, B. (2015). The influence of the audit report on the relevance of the accounting information reported by Listed Romanian Companies. Procedure Economics and Finance, 20, 562-570. https://doi.org/10.1016/5 2212.5671(15)00100.4

Soderstrom, N., \& Sun, K. J. (2007). IFRS adoption and accounting quality: A review. European Accounting Review, 16(4), 675-702. https://doi.org/10.1080/0963180701706732

Wang, Z., Ali, M., \& Al-Akra, M, (2012). Value relevance of voluntary disclosures and the global financial crises: Evidence from China. Managerial Auditing Journal, 28(5), 444-468. https://doi.org/10.1108/02.686901311327218

\section{Copyrights}

Copyright for this article is retained by the author(s), with first publication rights granted to the journal.

This is an open-access article distributed under the terms and conditions of the Creative Commons Attribution license (http://creativecommons.org/licenses/by/4.0/). 